\title{
Comparative Analysis of Nutritional Value of Oreochromis niloticus (Linnaeus), Nile Tilapia, Meat from Three Different Ecosystems
}

\author{
Fanuel Jim, ${ }^{1}$ Penina Garamumhango, ${ }^{2}$ and Colin Musara ${ }^{1}$ \\ ${ }^{1}$ Department of Preclinical Veterinary Studies, University of Zimbabwe, P.O. Box MP 167, Mount Pleasant, Harare, Zimbabwe \\ ${ }^{2}$ Masvingo Polytechnic, Department of Food Science, P.O. Box 800, Masvingo, Zimbabwe \\ Correspondence should be addressed to Colin Musara; colmus@vet.uz.ac.zw
}

Received 20 July 2016; Revised 7 October 2016; Accepted 24 October 2016; Published 12 January 2017

Academic Editor: Alejandro Hernández

Copyright (C) 2017 Fanuel Jim et al. This is an open access article distributed under the Creative Commons Attribution License, which permits unrestricted use, distribution, and reproduction in any medium, provided the original work is properly cited.

Determination of protein, lipid, and mineral content of fish meat is necessary to ensure that it meets requirements for food regulations and commercial specifications. The objective of the present study was to determine the chemical composition of Oreochromis niloticus (L.), Nile tilapia, under three different ecosystems: (1) high pollution and high density of Eichhornia crassipes, that is, water hyacinth (Lake Chivero), (2) medium pollution and medium density of water hyacinth (Lake Manyame), and (3) low pollution and low density of water hyacinth (Lake Kariba). Dry matter, protein, lipids, and ash were evaluated by proximate analysis. Minerals were determined by atomic absorption spectrophotometry and $\mathrm{pH}$ was determined by a pH meter. Lake Kariba fish had the highest percentage of dry matter, protein, and ash. These qualities were correlated to low levels of pollutants and high oxygen content in the harvest waters. The phosphorus content of fish from Lake Chivero was very high, in tandem with phosphate levels in the harvest waters. In addition, water from Lake Chivero had an alkaline $\mathrm{pH}$, high nitrate, and low oxygen content. The results suggest that effluent from sewage works and fertilizer industries caused pollution and proliferation of water hyacinth, contributing to pervasion of the chemical composition of fish.

\section{Introduction}

Fish is the cheapest source of animal protein for some communities including those who do not consume red meat, the malnourished, immunocompromised, pregnant women, and nursing mothers. Several species of fish have been part of the diet of some ethnic groups in all continents for a long time. Fishing makes the most widespread contribution to fish meat; commercial fish farming is limited. Due to its high protein content, fish is commonly used as relish. Fish have a high economic value derived through operation of fisheries and aquaculture which provide employment, recreation, trade, and economic well-being for those involved in the trade. Products from fishing are an important part of international trade, currently worth more than US $\$ 50$ billion [1]. Nutritionally, fish is considered an important and rich source of affordable protein. Fish consumption has been reported to contribute to almost $50 \%$ of the animal protein consumed in many Asian countries [2]. Fish protein is characterized by a desirable composition of amino acids [3]. The muscle consists of mainly myofibrillar proteins, sarcoplasmic proteins, connective tissue, stroma proteins, polypeptides, nucleotides, and nonprotein nitrogen compounds. Fish is also a rich source of group B vitamins as well as vitamins A and D [4]. Besides its acceptance as a balanced source of animal protein and vitamins, fish also provides polyunsaturated fatty acids (PUFAs) and minerals necessary for optimal health $[5,6]$. Fish also generate scientific interest in the development and processing of high quality protein food which retains its aroma, appearance, and colour. Apart from being used as food, fish is also increasingly demanded for use as feed. However, nutritional advantages of fish are limited by its rapidly perishable nature and therefore short shelf-life.

Data concerning the chemical composition of fish is essential to provide information on nutritious healthy foods of low fat and high protein content [7, 8]. In addition, fatty 
acid composition data are needed by food scientists and nutritionists in dietary formulation, food processing, and product development [9]. The study of chemical composition of fish is important since it influences keeping quality and technological characteristics of the fish [10]. Measurement of proximate profiles such as protein, lipids, and moisture content is often necessary to ensure that they meet the requirements of food regulations and commercial specifications [11]. They also influence postharvest processing and the shelf-life of the fish [12].

The nutritional composition of freshwater fish was found to differ between geographical localities [13]. The changing biological and environmental conditions are a useful tool to the ecologist. Ecologists require information on meat composition to help create or maintain dam water atmosphere conducive for rearing a quality fish meat carcass. So far there has been research on other effects on fish, but not much research has been done on the nutritional quality of the fish living in different ecosystems. The present study aimed to investigate the impact of different water sources on the quality of Oreochromis niloticus (Nile tilapia) from three different fresh water sources. Oreochromis niloticus is a popular fish and in Zimbabwe exists in abundance in Lake Kariba, Lake Chivero, and Lake Manyame. The catchment areas of the water sources are different. Lake Chivero's catchment introduces industrial effluent and raw sewage waste into the lake from large urban centres nearby. Lake Manyame's catchment area introduces 10 million litres of raw sewage into the lake from a neighbouring town every month. The catchment area of Lake Kariba is relatively free from waste and pollution. The quality of water is considered the main factor in fish quality and also affects reproduction of fish. In addition, continued deposition of effluent into Lake Chivero has abetted the spread of water hyacinth (Eichhornia crassipes) which thrives under constant supply of nitrates and phosphates in effluent from fertilizer industries. Due to the spread of the water hyacinth, the water in Lake Chivero tends to be highly deoxygenated compared to Lake Manyame where the weed is less prevalent. The water in Lake Kariba tends to be highly oxygenated as the water hyacinth is scant and only present in shallow water.

\section{Material and Methods}

2.1. Description of Study Site. The fish used in this study were sourced from three different ecosystems. The description of the three water bodies is shown in Table 1 .

Figure 1 shows the schematic catchment areas for Lake Manyame and Lake Chivero. The catchment for Lake Kariba straddles a wide area within southern Africa and parts of east Africa.

2.2. Collection of Water and Fish Samples. Water and fish samples were collected on the same day. A total of 30 samples of fish were collected comprising ten fish from each lake caught using the seine netting and gill netting method. The fish were placed in ice soon after the catch to keep them fresh.
TABle 1: Description of Lake Chivero, Lake Kariba, and Lake Manyame.

\begin{tabular}{lccc}
\hline Lake & $\begin{array}{c}\text { Surface } \\
\text { size }\end{array}$ & Climate/rainfall & $\begin{array}{c}\text { Catchment } \\
\text { area }\end{array}$ \\
\hline Kariba & $5580 \mathrm{~km}^{2}$ & $\begin{array}{c}\text { Hot temperatures } \\
\text { throughout the year. } \\
\text { November-March: } \\
\text { hot/rainy; May-August: } \\
\text { cold and dry; }\end{array}$ & $1352000 \mathrm{~km}^{2}$ \\
Chivero & $26.30 \mathrm{~km}^{2}$ & $\begin{array}{c}\text { September-October: hot } \\
\text { and dry. } \\
\text { Manyame }\end{array}$ & $2300 \mathrm{~km}^{2}$ \\
\hline & $81 \mathrm{~km}^{2}$ & Similar to Lake Chivero. & $\begin{array}{c}\text { Same as Lake } \\
\text { Chivero }\end{array}$ \\
\hline
\end{tabular}

Water samples were collected with a Ruttner sampler mounted to a speed boat, using the integrated surface down profile method to obtain a representative water sample [14]. The water was collected into duplicate sterile sample bottles, chilled in ice, and transported to the laboratory for analysis. Both the fish and water samples were sent to the Department of Animal Science and the Department of Biological Sciences Laboratories at the University of Zimbabwe for analysis.

2.3. Preparation and Analysis of Water Samples. A portion of the water sample was vacuum pumped to pass through a Millipore glass fibre prefilter (GFP) for the analysis of dissolved components. The water was analysed for dissolved oxygen, phosphates, nitrates, and $\mathrm{pH}$ using standard methods for fresh water analysis as described previously [15].

2.4. Laboratory Analysis of Fish Samples. Fish samples were subjected to proximate analysis as described by the Association of Official Analytical Chemists (AOAC) [16].

2.4.1. Fish Sample Preparation. Samples for fish analysis were taken from the left side of each fish. Samples were homogenised by passing them twice through a mincer with $4 \mathrm{~mm}$ holes and mixed thoroughly. Uniformity of the homogenate was ensured by further mixing with a domestic food processor. The resultant homogenate was packed into several small convenient sterile containers and stored at $0^{\circ} \mathrm{C}$ prior to laboratory analysis.

2.4.2. Protein Analysis. This was determined using the Kjeldahl process as described by AOAC. To $2 \mathrm{~g}$ of appropriately homogenised fish sample weighed into a Kjeldahl flask, $10 \mathrm{~g}$ of catalyst, $25 \mathrm{~mL}$ of concentrated $\mathrm{H}_{2} \mathrm{SO}_{4}$, and three glass beads were added. The contents were then digested with a mixture of powdered potassium sulphate, copper sulphate, and selenium mixed in the ratio of 94.8:5:0.2 until being clear. Contents were cooled and diluted and $100 \mathrm{~mL}$ of $40 \%$ sodium hydroxide was added. Exactly $50 \mathrm{~mL}$ of $4 \%$ boric acid was poured into a separate conical flask and connected to the distillation unit. The mixture was distilled and the distillate was collected into the boric acid containing 3 drops of indicator until the volume was above $150 \mathrm{~mL}$. Ammonia was converted to ammonium metaborate and titrated with 


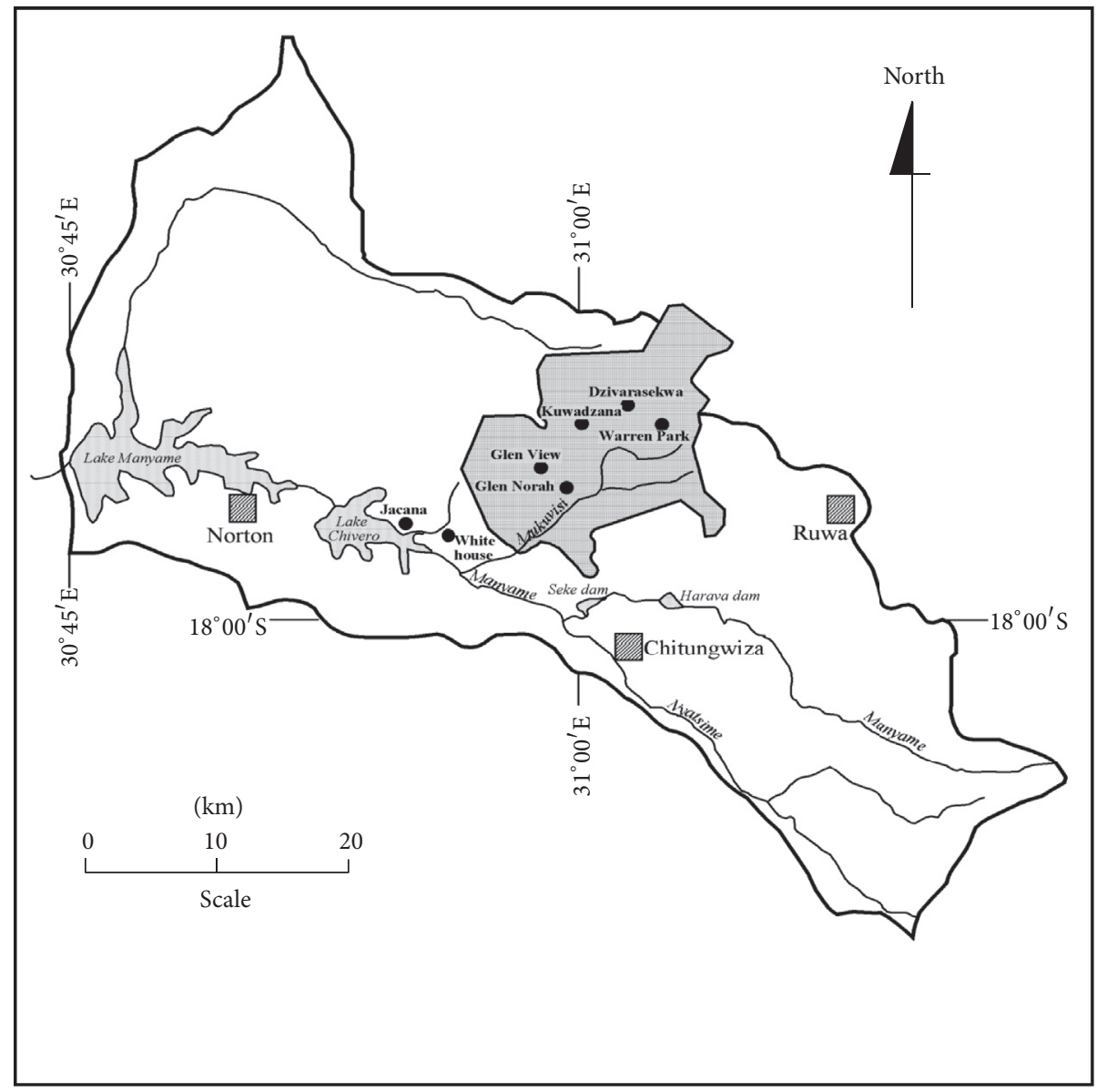

FIGURE 1: A schematic representation of the catchment area of Lake Manyame and Lake Chivero.

standardized $0.1 \mathrm{M}$ hydrochloric acid. The percentage of protein was calculated using the following formula:

$$
\begin{aligned}
& \text { \%Protein } \\
& =\frac{(\text { titre vol sample }- \text { titre vol blank }) \times 0.014 \times 0.1 \times 6.25}{\text { weight of sample used }} \\
& \quad \times 100 .
\end{aligned}
$$

The sample was analysed in triplicate.

2.4.3. Analysis of Crude Fat. Crude fat was analysed using the ether extract method. A $2 \mathrm{~g}$ dried fish sample was inserted into a predried porous thimble allowing rapid flow of petroleum ether. The sample was wrapped in filter paper, placed into the thimble, and covered with glass wool. Anhydrous ether was placed into a weighed boiling flask, which, together with the Soxhlet flask and condenser, was assembled into the Soxhlet apparatus. Fat was extracted into a Soxhlet extractor for 6 hours, by heating solvent in the boiling flask. The boiling flask with extracted fat was dried in an air oven at $100^{\circ} \mathrm{C}$ for 30 minutes, cooled in a desiccator, and weighed. The fat content was estimated as follows:

$$
\begin{aligned}
& \% \text { Fat } \\
& =\frac{\text { weight of flask and extracted fat }- \text { weight of empty flask }}{\text { weight of dried sample used }} \\
& \quad \times 100 .
\end{aligned}
$$

2.4.4. Determination of Dry Matter. Moisture was determined using the AOAC method of proximate analysis. Exactly $0.5 \mathrm{~g}$ of homogenised fish sample, taken in triplicate, was placed in a preweighed aluminium dish and placed in a hot air oven maintained at $105^{\circ} \mathrm{C}$ for 1 hour. The sample was cooled in a desiccator to room temperature and the loss in weight was calculated as a percentage as follows:

$$
\% \text { Moisture }=\frac{(\text { weight of sample before drying }- \text { weight of sample after drying) }}{\text { weight of sample before drying }} \times 100 \text {. }
$$


TABle 2: Quality of water from Lakes Chivero, Manyame, and Kariba.

\begin{tabular}{lcccc}
\hline Lake & $\begin{array}{c}\text { Dissolved } \\
\text { oxygen } \mathrm{mg} / \mathrm{L}\end{array}$ & $\begin{array}{c}\text { Phosphates } \\
\mathrm{mg} / \mathrm{L}\end{array}$ & $\begin{array}{c}\text { Nitrates } \\
\mathrm{mg} / \mathrm{L}\end{array}$ & $\mathrm{pH}$ \\
\hline Kariba & 11.00 & 6.58 & 0.15 & 7.60 \\
Manyame & 9.70 & 0.37 & 1.80 & 6.78 \\
Chivero & 7.40 & 27.13 & 32.60 & 9.71 \\
\hline
\end{tabular}

2.4.5. Measurement of Ash Content. A $5 \mathrm{~g}$ fish sample, taken in triplicate, was weighed into an empty preweighed crucible and placed in a muffle furnace which was then ignited for 12 hours at $550^{\circ} \mathrm{C}$. The furnace was turned off to cool to $250^{\circ} \mathrm{C}$ before sample removal. Sample was desiccated prior to weighing. The ash content was calculated as follows:

$$
\% \text { Ash }=\frac{\text { (weight of crucible plus sample after ashing }- \text { empty weight of crucible) }}{\text { weight of sample before ashing }} \times 100 \text {. }
$$

2.4.6. Evaluation of Minerals. Mineral content was determined from the ashed sample using an atomic absorption spectrophotometer. The minerals analysed were calcium, iron, potassium, magnesium, zinc, sodium, phosphate, cadmium, and copper. The minerals constituents were in parts per million which was converted by calculation to $\mathrm{mg} / 100 \mathrm{~g}$.

2.4.7. Measurement of $p H$. Measurements of the $\mathrm{pH}$ of fish meat were performed with a Jenaway $8014 \mathrm{pH}$ meter by placing the glass-calomel electrodes into a suspension of 1 gram of fish flesh in $100 \mathrm{~mL}$ of distilled water.

2.5. Data Analysis. Data on chemical composition of fish was entered in Excel and analysed using the Statistical Analysis System Version 9.3, SAS, 2010. Data was analysed using the generalized linear models procedure (PROC GLM) of SAS. Means were separated using the "lsmeans" methodology. The following model was used:

$$
Y_{i j}=\mu+T_{i}+e_{i j}
$$

where $Y_{i j}$ is the observation on the $j$ th fish; $\mu$ is the mean due to conditions common to all observations; $T_{i}$ is the effect of the $i$ th source of fish $(i=1,2,3) ; e_{i j}$ are the random residuals.

\section{Results}

3.1. Quality of Water. Table 2 shows the amount of dissolved oxygen, phosphates, and nitrates as well as the $\mathrm{pH}$ of the water from the three sources. Water from Lake Kariba had the highest concentration of dissolved oxygen, with Lake Manyame and Lake Chivero waters having much less. On the other hand, the concentrations of phosphates and nitrates were much higher in Lake Chivero in comparison to Lakes Manyame and Kariba. The $\mathrm{pH}$ of water from Lake Chivero was also higher than that of water from the other two sources.

3.2. Quality of Fish. Below are the descriptive statistics and results of analysis of the fish from the three sources.

3.2.1. Effect of Source of Fish on Dry Matter, Protein, Fat, and $\mathrm{pH}$ of Fish Meat. Results for dry matter, protein, fat, and $\mathrm{pH}$ are presented in Table 3 . The dry matter content, fat, protein, and $\mathrm{pH}$ were significantly $(P<0.05)$ influenced by the source of the fish. Fish from Lake Kariba had the highest levels of dry matter, ash, and protein but they were significantly lower in fat than fish from Lake Chivero, although similar to fish from Lake Manyame. The $\mathrm{pH}$ of fish from Lake Kariba was lower than that of the fish from Lake Chivero but similar to that of fish from Lake Manyame.

3.2.2. Effect of Source of Fish on Mineral Content of Fish. Table 4 shows the results of ash and mineral analysis. Although source of fish had a significant effect on the overall ash content of the fish meat, it had no effect $(P>0.05)$ on calcium, sodium, iron, zinc, and copper content of the fish. However, the content of magnesium, potassium, and phosphorus were significantly $(P<0.05)$ influenced by the source of the fish. Meat of fish from Lake Chivero was generally higher $(P<0.05)$ in the content of magnesium and phosphorus.

\section{Discussion}

4.1. Differences in Chemical Composition of Fish Meat according to Source. Protein content of fish from all three lakes ranged between $13.86 \%$ and $17.12 \%$, with Lake Kariba having the highest and Lake Manyame the least. Protein content in Lake Manyame fish (13.86\%) was lower than the average of $15-24 \%$ [17]. The results suggest that the Oreochromis niloticus from Lake Chivero and Lake Kariba was an adequate source of protein, which makes Oreochromis niloticus from these lakes an important source of dietary protein similar to other sea and fresh water fish [18]. However, the protein content of Oreochromis niloticus from Lake Manyame was slightly below $15 \%$ and therefore slightly inadequate. Lipid content is used to classify fish [9]. The fat content of fish in Lake Kariba and Lake Manyame, which was 1.74\% and 1.73\% respectively, classifies the flesh as lean and the fat content in Lake Chivero fish flesh, which was 3.17\%, is classified as low fat. The normal lipid content of Oreochromis niloticus is $2.75 \pm 0.16 \%$ [19]. Hence Lake Chivero fish contained a higher percentage of lipids whereas fish from the other two lakes had much less. Normally high-lipid fishes have less water and more protein than low-lipid fishes. Fish from Lake Chivero showed this kind of relationship. However, fish from 
TABLE 3: Ls mean dry matter, ash, fat, protein, and $\mathrm{pH}$ of fish (s.e. in parentheses).

\begin{tabular}{lccccc}
\hline Source lake & $\begin{array}{c}\text { Dry matter } \\
\%\end{array}$ & $\begin{array}{c}\text { Ash } \\
\%\end{array}$ & $\begin{array}{c}\text { Fat } \\
\%\end{array}$ & \multicolumn{2}{c}{$\begin{array}{c}\text { Protein } \\
\%\end{array}$} \\
\hline Kariba & $24.70^{\mathrm{a}}(0.725)$ & $3.30^{\mathrm{a}}(0.304)$ & $1.74^{\mathrm{a}}(0.335)$ & $17.12^{\mathrm{a}}(0.503)$ & $6.17^{\mathrm{a}}(0.111)$ \\
Manyame & $19.18^{\mathrm{b}}(0.725)$ & $1.76^{\mathrm{b}}(0.304)$ & $1.73^{\mathrm{a}}(0.335)$ & $13.86^{\mathrm{b}}(0.503)$ & $6.06^{\mathrm{a}}(0.111)$ \\
Chivero & $22.48^{\mathrm{a}}(0.725)$ & $2.27^{\mathrm{c}}(0.304)$ & $3.17^{\mathrm{b}}(0.335)$ & $16.45^{\mathrm{a}}(0.503)$ & $6.58^{\mathrm{b}}(0.111)$ \\
\hline
\end{tabular}

Means with different superscripts within column are significantly different from each other.

TABLE 4: Ls mean ash (\%) and mineral (mg/100 g) content of fish from three water bodies.

\begin{tabular}{lccccccccc}
\hline Source lake & Ash & $\mathrm{Mg}$ & $\mathrm{K}$ & $\mathrm{P}$ & $\mathrm{Ca}$ & $\mathrm{Na}$ & $\mathrm{Fe}$ & $\mathrm{Zn}$ & $\mathrm{Cu}$ \\
\hline Kariba & $3.30^{\mathrm{a}}$ & $24.17^{\mathrm{a}}$ & $387.17^{\mathrm{a}}$ & $175.00^{\mathrm{a}}$ & $59.00^{\mathrm{a}}$ & $18.33^{\mathrm{a}}$ & $4.50^{\mathrm{a}}$ & $0.95^{\mathrm{a}}$ & $0.71^{\mathrm{a}}$ \\
Manyame & $1.76^{\mathrm{b}}$ & $18.83^{\mathrm{a}}$ & $319.33^{\mathrm{b}}$ & $58.33^{\mathrm{b}}$ & $38.67^{\mathrm{a}}$ & $14.33^{\mathrm{a}}$ & $3.17^{\mathrm{a}}$ & $1.16^{\mathrm{a}}$ & $0.48^{\mathrm{a}}$ \\
Chivero & $2.27^{\mathrm{c}}$ & $46.00^{\mathrm{b}}$ & $429.33^{\mathrm{a}}$ & $308.33^{\mathrm{c}}$ & $33.17^{\mathrm{a}}$ & $18.00^{\mathrm{a}}$ & $3.17^{\mathrm{a}}$ & $1.22^{\mathrm{a}}$ & $0.35^{\mathrm{a}}$ \\
s.e. & 0.34 & 4.769 & 17.181 & 10.758 & 9.040 & 1.151 & 0.54 & 0.143 & 0.097 \\
\hline
\end{tabular}

Means with different superscripts within column are significantly different from each other.

Lake Kariba also exhibited higher protein levels although they had lower lipid content. In Lake Chivero, fish had 3.17\% fat against a protein content of $16.45 \%$ whereas Lake Kariba fish had $1.74 \%$ fat value against a protein content of $17.12 \%$. The analysis results indicate that the Oreochromis niloticus from all sources had normal amounts of essential minerals, namely, calcium, potassium, sodium, phosphorus, copper, and iron. Hence Oreochromis niloticus from all three lakes was an adequate source of minerals, just like most species of fish [20]. The normal ash content of Oreochromis niloticus meat is $2.6 \pm 0.2 \%$ [19]. Total mineral content (ash) was above average in fish from Lake Kariba and lower than normal in Lake Manyame fish, with fish from Lake Chivero in the median range. However, fish from Lake Chivero had more content in their flesh of magnesium and phosphorus. Normal levels of magnesium and phosphorous in Oreochromis niloticus meat are $27 \mathrm{mg} / 100 \mathrm{~g}$ and $170 \mathrm{mg} / 100 \mathrm{~g}$, respectively [21], values which are substantially lower than the $46.00 \mathrm{mg} / 100 \mathrm{~g}$ and $308.33 \mathrm{mg} / 100 \mathrm{~g}$ recorded in the present study. Normal moisture content of meat from Oreochromis niloticus was found to be $78.9 \pm 0.5 \%$, giving a dry matter value of $21.1 \pm$ $0.5 \%$ [19]. Of the three sources, only fish from Lake Manyame had a subnormal dry matter composition.

4.2. Review of Factors Affecting the Chemical Composition of Fish Meat. Differences in nutritional components of the fish could be as a result of the rate at which these components are available in the particular water body [22]. They could also be due to the capacity of the fish to absorb and assimilate the essential nutrients from the harvest water where they habitat or the available diet [23]. Oreochromis niloticus is an omnivore. The diet comprises a diversity of food items, including macrophytes [24], algae, zooplankton, insects, oligochaetes, caridina, and bivalves [25]. Whereas large zooplankton forms a significant component of the diet of Oreochromis niloticus, there is nonselective filtration of smaller phytoplankton organisms during feeding [26]. The nutritional components of freshwater fish differ between geographical localities [13].
Protein content is also negatively affected by the fish's spawning period [27]. The flesh lipid is controlled by the available nutrition $[28,29]$. Other factors could also come into play. These include the feeding frequency, sex, and maturity of the fish $[30,31]$. The minerals composition of fish meat is determined by the harvest waters. The concentration of minerals in the harvest waters influences the content of those minerals in the habitat fish.

4.3. Influence of Ecosystem on Chemical Composition of Fish Meat from Lakes Chivero, Manyame, and Kariba. In the present study, the most probable reason for the differences observed in fish from the three ecosystems was pollution of sewer and industrial effluents from large neighbouring urban centres into Lake Chivero and Lake Manyame. That, in turn, caused higher amounts of nutrients in the waters, leading to increased growth of water hyacinth that decreased the concentration of dissolved oxygen in the water. Consequently the chemical composition of fish from the two sources was negatively affected. Water hyacinth, an exotic floating macrophyte, was introduced into Zimbabwe in 1937. Growth of water hyacinth is influenced chiefly by the concentrations of phosphorous and nitrogen in the aquatic environment [32]. Maximum growth has been recorded in water fertilized with sewage effluent (219-657 tonnes/ha/year) as opposed to water with artificial fertilizers (75.6-191.1 tonnes/ha/year) [33]. Unabated inflow of sewer effluent into Lake Chivero and Lake Manyame thus provided optimum conditions for proliferation of the water hyacinth weed. Results from the present study support the concept that overgrowth of water hyacinth in fresh water bodies reduces the amount of oxygen dissolved in water. The amount of dissolved oxygen is a factor which also interacts with other factors such as fish size, stocking density, and fish behaviour to affect fish feeding [34]. Dissolved oxygen is a major factor affecting fish growth and survival in the tropics together with the ability to tolerate early morning low levels of dissolved oxygen. The ability of the fish to recover quickly from the physiological stress 
created by low dissolved oxygen may also improve growth rate by extending feeding duration. In previous studies [35], an oxygen concentration of $10.24 \pm 1.25 \mathrm{mg} / \mathrm{L}$ was found to be sufficient for health and performance of teleost fish whereas environmental hypoxia $(7.03 \pm 2.29 \mathrm{mg} / \mathrm{L})$ reduced the ability of fish to sustain metabolic processes. In consonance with these observations, the dry matter, protein, and ash content obtained in the present study were highest for fish from Lake Kariba which happened to have the optimum concentration of dissolved oxygen. On the contrary, environmental hypoxia in Lake Manyame may have contributed to levels of dry matter, protein, and ash being lowest in fish from this source. Besides reducing availability of oxygen to fish, proliferation of water hyacinth may directly reduce the dietary components available to fish by intercepting light and inhibiting growth of phytoplankton.

In addition to low levels of pollutants, the large size of Lake Kariba relative to the other two lakes could have impacted positively the dry matter, protein, and ash content of fish from that source by reducing stocking density and competition for food. Tilapias have a preference for shallow waters during feeding [36]; therefore they tend to feed on food items at the periphery of water bodies. The large surface of Lake Kariba provides expansive shorelines that are more than adequate for the feeding character of Oreochromis niloticus.

Lake Chivero had the highest density of water hyacinth of all three lakes. The weed is concentrated in shallow water along the shores because of inherent requirements for leaves to float on the water surface. Oreochromis niloticus is known to feed on the remains of water hyacinth [37]. As fish from Lake Chivero had the highest fat content of $3.17 \%$, this might be an indicator that the principal food of Oreochromis niloticus from this source was water hyacinth. Although plants are efficiently digested in fish that feed on macrophytes, the inherently low protein levels (7.61\% of fresh weight) in water hyacinth [38] mean that, for the fish to meet their protein requirements, feed intake has to increase. Ironically, this would result in an energy surplus which is reflected as a high fat content in the fish. Consumption of water hyacinth as the major dietary component may also explain the higher levels of magnesium in fish from Lake Chivero compared to the other sources since the weed has been shown to contain very high levels of magnesium, averaging $0.2-0.3 \%$ of the dry matter [39]. Proliferation of water hyacinth in Lake Chivero appears to be driven by the significantly higher levels of phosphate and nitrates in comparison to the other two sources. The high phosphorus and nitrate concentrations in Lake Chivero harvest water can be attributed to the dumping of industrial waste from the fertilizer industry and inflow of fertilizer from stream bank cultivation in addition to influx of sewage effluent. A high concentration of phosphorous in the harvest water could have resulted in the high phosphorus content of fish from Lake Chivero relative to fish from Lakes Kariba and Manyame, as shown in Table 2. This could be due to direct absorption of phosphate from ingested water or feeding on water hyacinth that has accumulated phosphorous from the ambient water. As creatine phosphate, phosphorous is an important mineral element in muscle energy metabolism but can become harmful when the concentration in fish tissues exceeds the metabolic demands [40].

\section{Conclusion}

The present analysis has broadened our knowledge on the nutritional value of Oreochromis niloticus under different ecological conditions. In particular, the effect of pollutants from sewer and industrial effluent on quality of water and chemical composition of fish meat has been clearly demonstrated. In addition, depletion of oxygen content of water by overgrowth of water hyacinth weed and concomitant changes in carcass dry matter, protein, fat, and mineral content have been enunciated. The present study could assist in determining the suitability of different ecosystems to production and safety of fish meat. Differences in chemical composition of fish could also influence postharvest processing and storage techniques. With the increase in demand for fish to fill in the gaps due to the high cost of other meats, this information is also useful in developing nutrient-balanced, cost-effective diets for human nutrition as well as suitable feeds for cultured fish.

\section{Additional Points}

Practical Applications. The present analysis has broadened our knowledge on the nutritional quality of Oreochromis niloticus under different ecological conditions. Effects of pollutants from sewer and industrial effluent on quality of water and chemical composition of fish meat have been demonstrated. Also, depletion of oxygen content of water by overgrowth of water hyacinth and concomitant changes in carcass quality have been enunciated. These findings could assist in determining the effect of different ecosystems on production and nutritional value of fish meat.

\section{Competing Interests}

The authors declare no conflict of interests regarding the publication this paper.

\section{Acknowledgments}

The authors wish to extent sincere thanks to Mr. S. Chikambi and Mr. G. Ashley for allowing them to do chemical analysis in the animal science and biological sciences laboratories. Sincere gratitude also goes to Mr. V. E. Imbayarwo-Chikosi for assistance with the data analysis and Dr. Halimani for his support.

\section{References}

[1] V. Venugopal, "Biosensors in fish production and quality control," Biosensors and Bioelectronics, vol. 17, no. 3, pp. 147-157, 2002.

[2] C. William and C. Dennis, Food Microbiology, McGraw-Hill Book Company, Singapore, 4th edition, 1988. 
[3] S. P. Aubourg and I. Medina, "Influence of storage time and temperature on lipid deterioration during cod (Gadus morhua) and haddock (Melanogrammus aeglefinus) frozen storage," Journal of the Science of Food and Agriculture, vol. 79, no. 13, pp. 19431948, 1999.

[4] T. Zmijewski, R. Kujawa, B. Jankowska, A. Kwiatkowska, and A. Mamcarz, "Slaughter yield, proximate fatty acid composition and sensory properties of rapfen (Aspius aspius $\mathrm{L}$ ) with tissue of bream (Abramis brama L) and pike (Esox lucius L)," Journal of Food Composition and Analysis, vol. 19, no. 2-3, pp. 176-181, 2006.

[5] A. E. Andrew, Fish Processing Technology, University of Ilorin Press, Ilorin, Nigeria, 2001.

[6] S. T. Arannilewa, S. O. Salawu, A. A. Sorungbe, and B. B. OlaSalawu, "Effect of frozen period on the chemical, microbiological and sensory quality of frozen tilapia fish (Sarotherodun galiaenus)," African Journal of Biotechnology, vol. 4, no. 8, pp. 852-855, 2005.

[7] D. Mozaffarian, R. N. Lemaitre, L. H. Kuller, G. L. Burke, R. P. Tracy, and D. S. Siscovick, "Cardiac benefits of fish consumption may depend on the type of fish meal consumed," Circulation, vol. 107, no. 10, pp. 1372-1377, 2003.

[8] J. A. Foran, D. H. Good, D. O. Carpenter, M. C. Hamilton, B. A. Knuth, and S. J. Schwager, "Quantitative analysis of the benefits and risks of consuming farmed and wild salmon," Journal of Nutrition, vol. 135, no. 11, pp. 2639-2643, 2005.

[9] R. G. Ackman, "Nutritional composition of fats in sea foods," Progress in Food and Nutrition Science, vol. 13, pp. 161-289, 1989.

[10] H. H. Huss, Fresh Fish Quality and Quality Changes, FAO Fisheries no. 29, FAO, Rome, Italy, 1988.

[11] J. J. Waterman, Composition and Quality of Fish: A Dictionary, Torry Research Station, Edinburgh, UK, 2000.

[12] S. Clement and R. T. Lovell, "Comparison of processing yield and nutrient composition of cultured Nile tilapia (Oreochromis niloticus) and channel catfish (Ictalurus punctatus)," Aquaculture, vol. 119, no. 2-3, pp. 299-310, 1994.

[13] T. Zenebe, G. Ahlgren, I.-B. Gustafsson, and M. Boberg, "Fatty acid and lipid content of Oreochromis niloticus L. in Ethiopian lakes-dietary effects of phytoplankton," Ecology of Freshwater Fish, vol. 7, no. 3, pp. 146-158, 1998.

[14] M. R. Ndebele, "Primary production and other limnological aspects of Cleveland dam, Harare, Zimbabwe," Lakes \& Reservoirs: Research \& Management, vol. 14, no. 2, pp. 151-161, 2009.

[15] J. Batram and J. BAlance, Water Quality Monitoring: A Practical Guide to the Design and Implementation of Fresh Water Quality Analysis Studies and Monitoring Programs, Spon Press, London, UK, 2001.

[16] Association of Official Analytical Chemists, Official Methods of Analysis, Association of Official Analytical Chemists, Washington, DC, USA, 17th edition, 2000.

[17] T. Suzuki, "What is frozen minced meat?" in Fish and Krill Protein: Processing Technology, Applied Science, London, UK, 1981.

[18] P. Vlieg and T. Murray, "Proximate composition of albacore tuna, Thunnus alalunga, from the temperate South Pacific and Tasman Sea," New Zealand Journal of Marine and Freshwater Research, vol. 22, no. 4, pp. 491-496, 1988.

[19] M. M. Gaber, "Growth of Nile tilapia fingerling (Oreochromis niloticus) fed diets containing different levels of clove oil," Egyptian Journal of Aquatic Biology and Fisheries, vol. 4, pp. 1$18,2000$.
[20] J. E. Kinsella, "Fish and seafoods: nutritional implications and quality issues," Food Technology, vol. 42, no. 5, pp. 146-150, 1988.

[21] Agricultural Research Service (ARS), USDA, Nutrient data Release 22, 2009, http://www.nal.usda.gov/fnic/food-comp/.

[22] M. I. Yeannes and M. E. Almandos, "Estimation of fish proximate composition starting from water content," Journal of Food Composition and Analysis, vol. 16, no. 1, pp. 81-92, 2003.

[23] O. O. Fawole, M. A. Ogundrian, T. A. Ayandiran, and O. F. Olagunju, "Mineral composition in some selected fresh water fishes in Nigeria," Journal of Food Safety, vol. 9, pp. 52-55, 2007.

[24] E. A. Khallaf and A. A. Alne-na-ei, "Feeding ecology of Oreochromis niloticus (Linnaeus) \& Tilapia Zillii (Gervias) in a Nile canal," Hydrobiologia, vol. 146, no. 1, pp. 57-62, 1987.

[25] M. Njiru, J. B. Okeyo-Owuor, M. Muchiri, and I. G. Cowx, "Shifts in the food of Nile tilapia, Oreochromis niloticus (L.) in Lake Victoria, Kenya," African Journal of Ecology, vol. 42, no. 3, pp. 163-170, 2004.

[26] F. A. R. Elhigzi, S. A. Haider, and P. Larsson, "Interactions between Nile tilapia (Oreochromis niloticus) and cladocerans in ponds (Khartoum, Sudan)," Hydrobiologia, vol. 307, no. 1-3, pp. 263-272, 1995.

[27] A. K. Alams, Chemistry and Microbiology of Fish and Fish Processing, Department of Biochemistry, Norwegian Institute of Technology, University of Trondheim, Trondheim, Norway, 1981.

[28] J. A. Nettleton and J. Exler, "Nutrients in wild and farmed fish and shellfish," Journal of Food Science, vol. 57, no. 2, pp. 257-260, 1992.

[29] R. George and R. Bhopal, "Fat composition of free living and farmed sea species: implications for human diet and sea farming techniques," British Food Journal, vol. 97, no. 8, pp. 19-22, 1995.

[30] K. D. Shearer, "Factors affecting the proximate composition of cultured fishes with emphasis on salmonids," Aquaculture, vol. 119 , no. 1, pp. 63-88, 1994.

[31] P. C. Morris, "The effects of nutrition ion the composition of farmed fish," in Farmed Fish Quality, S. C. Kestin and P. D. Warris, Eds., Fishing New Books, London, UK, 2001.

[32] J. R. Wilson, M. Rees, N. Holst, M. B. Thomas, and G. Hill, "Water hyacinth population dynamics," in Biological and Integrated Control of Water Hyacinth, Eichhornia crassipes, M. H. Julien, M. P. Hill, T. D. Centre, and D. Jianqing, Eds., vol. 102 of ACIAR Proceedings, pp. 96-104, 2001.

[33] D. Little and J. Muir, A Guide to Integrated Warm Water Aquaculture, Institute of Aquaculture Publications, University of Stirling, Stirling, Scotland, 1987.

[34] D. Houlihan, T. Boujard, and L. Jobling, Food Intake in Fish, Blackwell Science, Oxford, UK, 2001.

[35] N. D. Martins, W. A. Colvara, F. T. Rantin, and A. L. Kalinin, "Microcystin-LR: how it affects the cardio-respiratory responses to hypoxia in Nile tilapia, Oreochromis niloticus," Chemosphere, vol. 84, no. 1, pp. 154-159, 2011.

[36] D. J. Macintosh and S. S. De Silva, "The influence of stocking density and food ration on fry survival and growth in Oreochromis mossambicus and $O$. niloticus female $\times O$. aureus male hybrids reared in a closed circulated system," Aquaculture, vol. 41, no. 4, pp. 345-358, 1984.

[37] N. J. Jihulya, "Diet and feeding ecology of Nile tilapia, Oreochromis niloticus and Nile perch, Lates niloticus in protected and unprotected areas of Lake Victoria, Tanzania," International Journal of Scientific \& Technology Research, vol. 3, pp. 280-286, 2014. 
[38] F. C. Okoye, F. Daddy, and B. D. Ilesanmi, "The nutritive value of water hyacinth (Eichhornia crassipes) and its utilization in fish feed," in Proceedings of the International Conference on Water Hyacinth, pp. 65-70, New Bussa, Nigeria, December 2000.

[39] B. Wolverton and R. C. Macdonald, "Don't waste waterweeds," New Scientist, vol. 72, pp. 318-320, 1976.

[40] C. Hogstrand and C. M. Wood, "The physiology of zinc in teleost fish. SEB seminar series-Aquatic Toxicology," in SEB Seminar Series-aquatic Toxicology, E. W. Taylor and M. Murphy, Eds., vol. 157, Cambridge University Press, Cambridge, UK, 1996. 

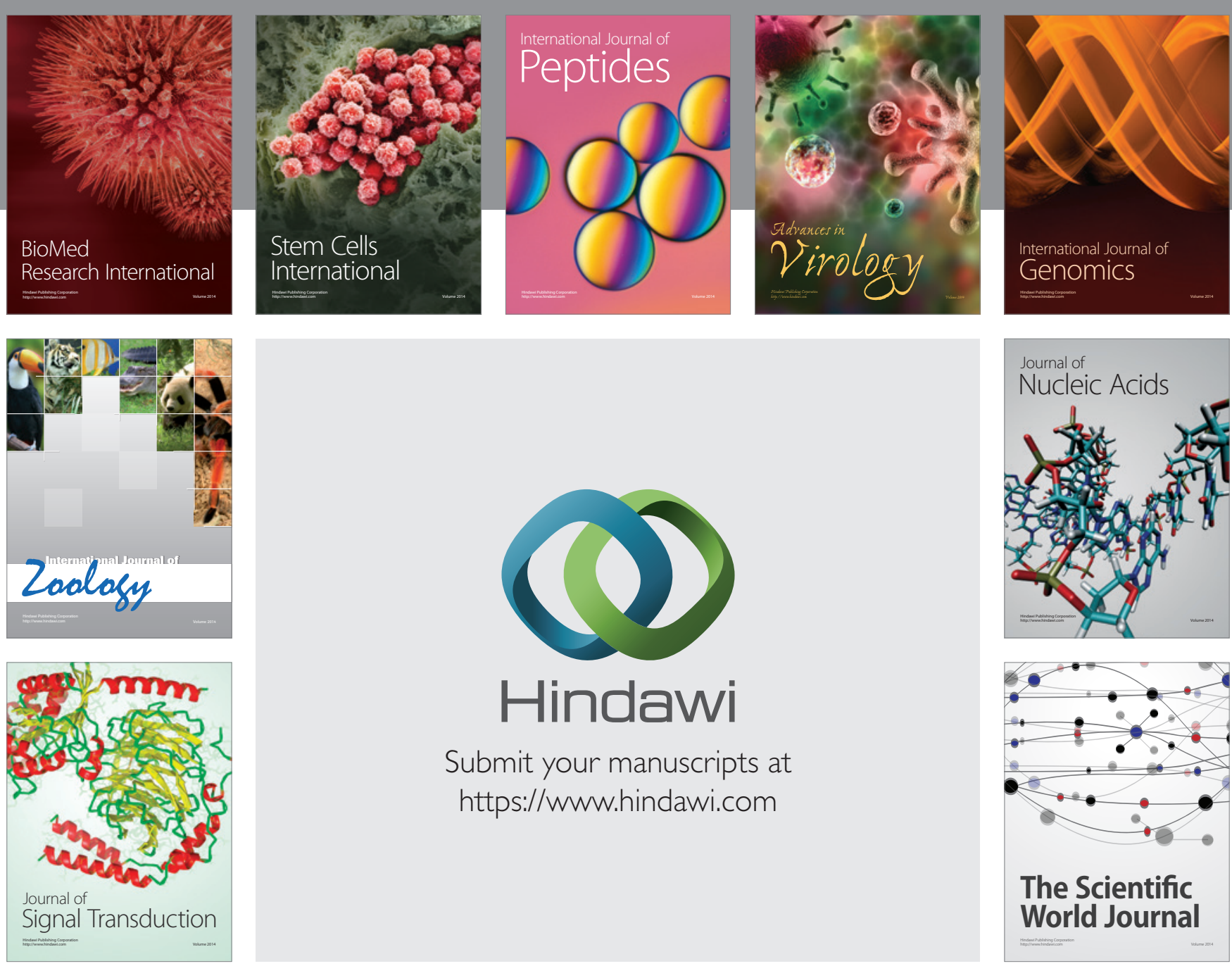

Submit your manuscripts at

https://www.hindawi.com
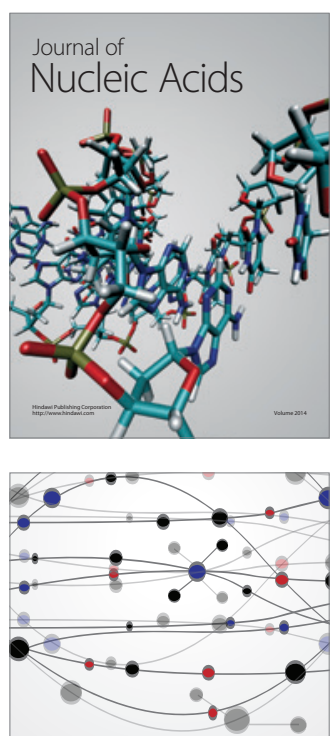

The Scientific World Journal
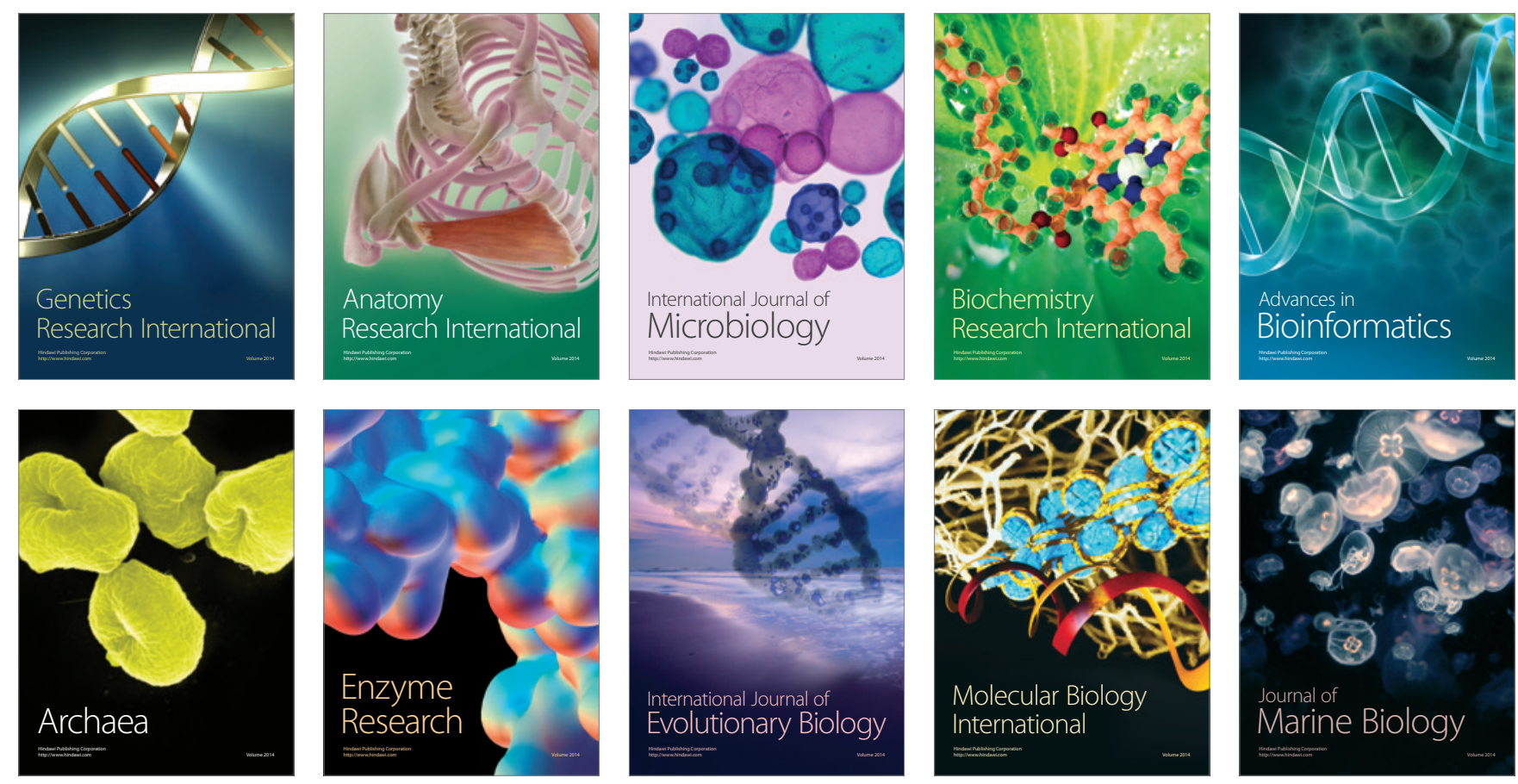